\title{
PRIVILEGED COMMUNICATIONS: IS JUSTICE SERVED OR OBSTRUCTED BY CLOSING THE DOCTOR'S MOUTH ON THE WITNESS STAND?
}

\author{
BY ZECHARIAH CHAFEE, JR. $\dagger$
}

Physicrans and surgeons are required by the ethics of their profession to preserve the secrets of their patients which have been conmunicated to them or learned from the inspection of symptoms and other bodily conditions. How far this ethical requirement should be enfurced by law is a question on which there is much difference of opinion amung both lawyers and doctors. ${ }^{1}$

No state has made disclosure of confidence a crime, but in some the license to practice may be revoked for this cause. Seventeen states still seem to preserve the view of the English common law that there is no legal check upon the revelation of medical secrets. On the witness stand, at all events, a doctor in these states must tell all he knows. 2 The remaining states adopt a half-way attitude towards the obligation of secrecy, of which the New York statute is typical." Unless the patient consents, the doctor is not allowed, while testifying in court, "to disclose any information which he acquired in attending a patient in a professional capacity and which was necessary to enable him to act in that capacity." Thus there is no liability to the patient if the doctor tells every last detail in clubroom gossip or in the thickly veiled items of a medical journal, but he is prohibited from divulging any of the truth in the place where it is usually most stringently required-the witness stand. Some of these statutes make exceptions for special medical situations where disclosure is badly needed, like abortion.* And several of the states recognizing the

$\dot{T}$ Langdell Professor of Law, Harvard Law School.

1. For a classic discussion of this problem, see 8 Wigmone, Evire:ece (3d ed. 1940) $\$ \S 2380-91$. See also (1921) 152 L. T. 53 (debates at British Miedieal Assaciation); (1922) 153 L. T. 228,252 (debates at British Medicu-Legal Suciety); (1937) 83 I. J. 320 (debates in House of Commons).

2. These states are Alabama, Connecticut, Delaware, Florida, Geurgia, Illinuis, Maine, Maryland, Massachusetts, New Hampshire, New Jersey, Rude Island, Swuth Carolina, Tennessee, Texas, Vermont, and Virginia.

3. This statute was first enacted in 1828. See N. Y. Civil Prictice Acr (1920) $\$ \S 352,354$, as subsequently amended.

4. 8 Wigarore. Evidence, $\S 2380$, n. 5, gives full references to the state statutes. The ensuing list mentions only the date of the original enactment without regard to subsequent amendments. The statutes vary in their terms, particularly as to waiver of the privilege. The ensuing list mentions only variations of especial medical interest, including the fact of adoption of the Uniform Narcotic Drug Act (U. N. D. A.): Alasha (1913) (except for insanity) ; Arizona (1913) (U. N. D. A.); Arkansas (1919); Cali- 
doctor-patient privilege in general have adopted the Uniform Narcotic Drug Act, which provides that "information communicated to a physician in an effort unlawfully to procure a narcotic drug, or unlawfully to procure the administration of any such drug, shall not be deemed a privileged communication." 5

Although the general policy of the law is to obtain as many facts as possible about a controversy on trial, rules of evidence of ten exclude reliable testimony if it was acquired by the witness through some confidential relation. A husband would hesitate to tell his wife about damaging facts and the thorough intimacy of marriage would be turned into watchful suspicion and reticence, if the law did not refuse to make her the means of his undoing. ${ }^{6}$ Likewise a man might not consult an honest lawyer, or if he did, would tend to keep back from him anything that looked unfavorable to the case, if the lawyer could be made the leading witness against him and forced to reveal all that was told him by his client. So the lawyer cannot speak without his client's consent. ${ }^{7}$ In many states a statute protects the secrets of the confessional; ${ }^{8}$ and even without such legislation few lawyers would have the hardihood to ask that a priest who keeps silent should be imprisoned for contempt of court.

Some doctors may feel that it is an unfair discrimination against their profession if lawyers' secrets are protected from disclosure in court fornia (1872) (except for mental condition and venereal disease); Canal Zonc (1934); Colorado (1921) ; District of Columbia (1919) (U. N.D. A.); Georgia (1935); Hawaii (1925) (U. N. D. A.) ; Idaho (1919) ; Indiana (1926) ; Iowa (1897) (U. N. D. A.) ; Kansas (1923) ; Kentucky (1915) ; Louisiana (1928) ; Maryland (1935) (U. N. D. A.) ; Mich* igan (1915) (except for illegal marriage of persons sexually diseased) ; Minnesota (1913) (except for bastardy) ; Mississippi (1906) : Missouri (1919) (except for abortion) ; Montana (1935) (U. N. D. A.) ; Nebraska (1922) (U. N. D. A.) ; Nevada (1912) (U. N. D. A.) ; New Mexico (1929) (U. N. D. A.); New York (1828) (except for narcotic investigations); North Carolina (1919) (allows presiding judge of superior court to compel disclosure when necessary to administration of justice, U. N. D. A.) ; North Dakota (1913) ; Ohio (1921) (U. N. D. A.) : Oklahoma (1931) (U. N. D. A.); Oregon (1920) (U. N. D. A.) ; Pennsylvania (1895); Philippine Islands (1901) ; Puerto Rico (1911) (except for malpractice, U. N. D. A.); South Carolina (1934) (U. N. D. A.) ; South Dakota (1919) (U. N. D. A.) ; Utah (1917) (U. N. D. A.) ; Virgin Islands (1920); Washington (1909); West Virginia (1897) (U. N. D. A.); Wisconsin (1919) (except for lunacy and malpractice, U. N. D. A.); Wyoming (1920) (U. N. D. A.).

5. Uniform Narcotic Drug Act, $\S 17, \llbracket 2$. This statute has been adopted in the following states and territories, of which those starred in the list do not recognize a general doctor-patient privilege: Arizona, District of Columbia, Hawaii, Iowa, Maryland," Montana, Nebraska, Nevada, New Mexico, North Carolina, Ohio, Oklahoma, Orcgon, Puerto Rico, South Carolina, " South Dakota, Tennessee,* Texas,* Vermont, West Virginia, Wisconsin, Wyoming.

6. See 8 Wignore, EVidence, $\$ \$ 2332-41$.

7. $I d, \S \S 2290-2329$. Full arguments for and against this privilege are given in $\S 2291$.

8. Id. $\S \$ 2394-96$. 
and yet physicians' secrets must be laid bare. Perhaps lawyers as well as doctors should be forced to divulge information when the judge thinks disclosure essential to the public interest, and proposals are now under consideration for extensive modifications of the attorney-and-client privilege. ${ }^{9}$ However, the success or failure of these proposals ought not to affect the question whether medical secrets should be inviolable in court. The relation between lawyer and client does differ materially from the relation between doctor and patient, and each privilege should be judged on its own merits. The administration of justice ought not to be shaped by inter-professional jealousies and trivial claims to prestige. Instead, we can all agree that it is a misfortune when a lawsuit is won by the party who would lose it if all the facts were known, and that we increase the risk of such a miscarriage of justice whenever we allow an important witness to keep any helpful facts away from the judge and jury. Secrecy in court is prima facie calamitous, and it is permissible only when we are very sure that frankness will do more harm than good. 'With doctors' secrets as with any other kind of secrets, the only proper test is the welfare of the community. Courtroom secrecy in the particular case must produce a public good which more than offsets the risks resulting from the concealment of truth and from the lies which can be made with less fear of detection. If the doctor-patient privilege should prove to be socially undesirable, doctors, possessing a high professional sense of public welfare, should be among the first to oppose it.

The reasons usually advanced for extending the privilege of silence to the medical profession are not wholly satisfactory. First, it is said that if the patient knows that his confidences may be divulged in future litigation he will hesitate in many cases to get needed medical aid. But although the man who consults a lawyer usually has litigation in mind, men very rarely go to a doctor with any such thought. And even if they did, medical treatment is so valuable that few would lose it to prevent facts from coming to light in court. Indeed. it may be doubted whether, except for a small range of disgraceful or peculiarly private matters, patients worry much about having a doctor keep their private affairs concealed from the world. This whole argument that the privilege is necessary to induce persons to see a doctor sounds like a philosopher's speculation on how men may logically be expected to behave rather than the result of observation of the way men actually behave. Not a single New England state allows the doctor to keep silent on the witness stand. Is there evidence that any ill or injured person in New England has ever stayed from a doctor's office on that account?

The same a priori quality vitiates a second argument concerning the evils of compelling medical testimony, namely, that a strong sense of

9. See Miorgan, Suggested Remedy for Obstructions to Expert Testimony by Rules of Evidence (1943) 10 U. OF CHI. L. REv. 285. 
professional honor will prompt perversion or concealment of the truth. Has any member of the numerous medical societies in New England observed such a tendency among New England doctors to commit perjury for the sake of "professional honor"? In reality, there is far more danger of perjury if the physician cannot testify, only it will be perjury by the patient. In many states where the privilege exists, an unscrupulous plaintiff in an accident case can exaggerate the injury without fear of contradiction by the doctor whom he consulted right after the accident. The patient can tell the sad story of his injuries to judge, jury, and spectators, and then he can object that it would violate his bodily privacy if the doctor were allowed to take the stand and testify that the accident had left no traces one hour after it occurred. Fortunately, there is some limit to this absurdity, for most courts hold that if the patient goes into the details of his injuries, he has waived his privilege and has thrown open the whole question of his bodily conditions. ${ }^{10}$ Otherwise he could make the statute both a sword and a shield. But even this rule about waiver does not promote truth-telling any too well. The patient may tell some rather big lies about his health without "going into details," and the courts are by no means clear in defining the point where details begin. There is also abundant confusion on the question whether what the patient says under crossexamination opens the door for his doctor to testify. Some courts hold that cross-examination is not a waiver like direct testimony, because the patient does not now speak willingly. By this view, the opposing lawyer who ventures to ask the patient any questions may find the witness going into the most intimate details without regard to either privacy or truth, and yet the lawyer will be helpless to contradict this highly colored story by calling the physician. ${ }^{11}$

Another argument for the privilege is that employees are often treated after accidents by physicians who are in charge of the company hospital or otherwise dependent upon the good will of the employing corporation. It was urged to legislatures that some of these physicians were taking ad-

10. The cases are collected in Note (1938) 114 A. L. R. 798. Sec also 8 WtGrore, EVIDENCE, $\$ 2389$.

11. The absurdity of this solicitude for the patient's privacy is illustrated by Harpman v. Devine, 133 Ohio St. 1, 10 N. E. (2d) 776 (1937), 11 U. of CiN. L. Rev. 544. The plaintiff sued the owner of a building for heavy damages, charging that the defendant negligently suspended a fire hose from the building in such a manner that a violent wind caused the hose to break a window, knocking glass against the plaintiff. $\mathrm{He}$ testified that since this accident he had suffered loss of weight, severe and chronic headaches, failing eyesight, insomnia, facial paralysis, and inability to walk normally; but that before the glass hit him his general condition was "very good." On cross-cxamination he admitted that he had consulted various physicians before the accident. The defendant called one of these doctors for the purpose of showing that the plaintiff was suffering from anemia before the accident, but the court refused to allow the doctor's evidence "in view of the very delicate and confidential nature of the relation." 
vantage of their position to obtain from the patients information which would tend to defeat a claim for damages. This argument has the merit of not being abstract, but of asserting a basis in fact. Yet even if it is valid, it might be wiser to admit the evidence of the physicians, trusting in the jury to discount it heavily if an improper attitude towards the patients exists.

Where the statutory privilege is in force, what is its scope? In the first place, what sort of medical person is included? ${ }^{12}$ Any licensed physician or surgeon falls within the statute. and this applies to hospital physicians though they are not specifically selected by the patient. ${ }^{13}$ There is no privilege for communications to unlicensed practitioners. Thus mental healers, chiropractors and osteopaths can be forced to disclose communications from their patients, unless perhaps their professional status is expressly recognized by law. Nor does the privilege apply to an unlicensed "orthopedist" who is teaching gymnastic exercises taken by medical advice. ${ }^{14}$ And those psychoanalysts who have been too busy to study medicine must have spicier facts to relate than physicians, but no court has yet bound them to secrecy. How about the numerous assistants who surround doctors under modern conditions? Many attempts have been made to prevent nurses from telling about their patients, but these have usually failed. ${ }^{10}$ Most courts say that if public policy demands the extension of the privilege to nurses and other hospital attendants, then the change in the law should be made by the legislature, not by judicial action. Here is an enticing invitation to organizations of nurses to increase their professional prestige by lobbying for a statutory amendment which will put them on the same high level of secrecy as doctors, a result which has already been accomplished in New York and a few other states. Dentists, druggists and veterinaries ${ }^{16}$ may also resent being left out in the cold.

No end of trouble has arisen about the admissibility of medical records. If a doctor cannot tell the court what he saw, then the hospital records in which he wrote down what he saw seem logically just as unavailable. Yet some courts are impressed by the fact that the law requires such rec-

12. The cases are collected in Note (1930) 68 A. L. R. 176; 8 Wigsose, Evidarice, $\S 2382$.

13. The cases are collected in Note (1923) 22 A. L. R. 1217; (1938) 72 U. S. Law REv. 619.

14. See Laurie Co. v. McCullough, 174 Ind. 477, 92 N. E. 337 (1910).

15. The cases are collected in Notes (1925) 39 A. L. R. 1421, (1930) 68 A. L. R. 176. On hospital attendants, see (1938) 22 MIARo. L. REv. 211.

16. The status of veterinaries was raised in Hendershot v. Western Union Telegram Co., 106 Iowa $529,76 \mathrm{~N}$. W. 828 (1S98), a suit brought by the owner of a race horce against the Western Union for delay in transmitting a telegram, "Bravo is sicls; come at once" The doctor arrived at last, but Bravo died. The Western Union lawyer asked the doctor what the owner said to him about Bravo's symptoms. The owner urged that the communications from him to the veterinary were privileged, but the court held that veterinaries were not covered by the statute. 
ords to be kept, and see little sense in this if they cannot be used for the sake of attaining justice. ${ }^{17}$ For example, it would be absurd if the records of a state hospital for the insane could not be consulted in a will contest for their bearing on the mental capacity of the testator. ${ }^{18}$ So judges have been inclined to read a wide exception into the statute to cover such situations. Thus death certificates ought to be admissible. ${ }^{10}$ In New York this exception has also been extended to public health records, which were admitted to show that the defendant was a typhoid carrier who had been warned not to participate in the service of food. The records were used to establish her liability in damages to the estate of a man who died of typhoid after eating food which had passed through her hands. ${ }^{20}$

Autopsies add further confusion. It is generally held that if the doctor did not attend the person during his lifetime, then the doctor can testify about performing an autopsy because the relation of the physician and patient did not exist. 21 "A deceased body is not a patient."22 For exanple, a man who carried heavy accident insurance became suddenly ill, and the physician who was called removed him to a hospital and there continued to treat him until his death. The hospital pathologist was then summoned to perform an autopsy, which showed that the man died from the effect of wood alcohol in home-made gin. Although the first doctor was merely allowed to give his opinion that wood alcohol in gin was calpa* ble of causing the death, the second doctor was permitted to give all the details discovered during the autopsy. ${ }^{23}$ Yet another court, regarding this device of evading the statutory privilege by switching doctors as an arrant subterfuge, concluded that a physician performing an autopsy "steps into the shoes of the attending physician, and must be treated as if he werc the assistant of the attending physician, holding the autopsy at the direction of the latter, and that the information acquired by him through the autopsy is privileged." 24

The requirement that the physician's knowledge about the patient be received in a professional relation raises great difficulties. Not everything medical that a doctor sees or hears is privileged. For example, if called to a house to see one person, the doctor can sometimes tell what he inciden-

17. The cases are collected in Notes (1931) 75 A. L. R. 378, (1939) 120 A. L. R. 1124.

18. See Liske v. Liske, 135 N. Y. Supp. 176 (N. Y. Sup. Ct. 1912).

19. Yet some courts exclude them. See the authorities in 8 Wignone, Evidence, \$2385a; Notes (1922) 17 A. L. R. 359, (1926) 42 A. L. R. 1454, (1935) 96 A. L. R. 324.

20. Thomas v. Morris, 286 N. Y. 266,36 N. E. (2d) 141 (1941), 136 A. L. R. 856.

21. The cases are collected in Note (1929) 58 A. L. R. 1134; 35 LAw Notes 8\% (N. Y. 1931).

22. Travelers' Ins. Co. v. Bergeron, 25 F. (2d) 680 (C. C. A. 8th, 1928).

23. Ibid.

24. Mathews v. Rex Health \& Accident Ins. Co., 86 Ind. App. 335,157 N. E. 467 (1927). 
tally observed as to the health of other members of the family. ${ }^{25}$ Though it would seem that symptoms which were obvious to every one without medical inspection cannot be said to be disclosed in confidence, several cases have forbidden hospital doctors to testify that when a man was brought in they smelled liquor on his breath or observed other common symptoms of intoxication. ${ }^{23}$ If the patient voluntarily employs the physician, the privilege is clear. But suppose the doctor renders first aid to an unconscious man. No confidence is reposed. but the doctor does attend him in a "professional capacity." In a New York case a physician was called by a hotel to attend a guest without the latter's knowledge. The man said he had taken poison, but cursed the doctor and refused to have anything to do with him, although the doctor administered a hypodermic. The hotel guest was held to be a patient, although he did not want to be, and the doctor was forbidden to tell about the poison in order to show that the patient had forfeited his life insurance by committing suicide. ${ }^{2 \pi}$

Even though a professional relation exists, only information necessary to enable the doctor to act in that capacity is privileged. Matters which are entirely distinct from medical facts may be disclosed, ${ }^{25}$ such as the patient's remarks about his will. An Indiana doctor was called to attend a sick wife and also cast a professional eye on her husband. IThile leaving the house, he heard the husband say, "I will get her yet, damn her; I will get her yet." Shortly afterwards the wife shot her husband. W'hen tried for murder, she called the doctor as a witness to support her story that she killed her husband in self-defense while he was approaching her with an open knife in his hand. The trial court excluded the doctor's evidence on the ground that he was in the house in the capacity of a physician: the jury disbelieved the wife's story, and she was convicted of manslaughter. The upper court reversed, however, holding that the doctor should have been allowed to testify about threats of death though not about health." ${ }^{28}$

Often the illness and another fact are closely connected, as in a New York divorce trial where a physician was asked to disclose a communication from the misguided wife as to the paternity of an expected child. The referee excluded this communication, because it must have been given as a sequel to the wife's disclosure of her pregnancy, which was clearly privileged and could not be repeated. On the other hand, a California doctor was allowed to testify that while he was delivering an illegitimate child a certain man was present and admitted that he was the father. ${ }^{53}$

25. See Jennings v. Supreme Council, 81 App. Div. 76, $\$ 1$ X. Y. Supp. 90 (1st Dep't 1903) ; Nichols v. State, 109 Neb. 335, 191 N. W. 333 (1922).

26. The cases are collected in Note (1932) 79 A. L. R. 1131.

27. Meyer v. Knights of Pythias, 178 N. Y, 63, 70 N. E. 111 (1904).

28. The cases are collected in S WIGMore, Evmexce, $\$ 2383$; Nute (1923) 34 A. L. R, 1202: (1938) 13 WASH. L. REv. 141.

29. Myers v. State, 192 Ind. 542, 137 N. E. 547 (1922).

30. In re Baird's Estate, 173 Cal. 617, 160 Pac. 1078 (1916). 
A similar question arises when the victim of an accident describing his symptoms to a physician throws in occasional statements about the way he was hurt. But it seems clear that the speed of the trolley car which hit him has no more bearing on the application of surgical dressings than the legitimacy of an expected child has on the medicines or other pre-natal care which should be given to the mother. ${ }^{31}$

Logically it may be that the facts leading up to a physical condition are often not necessary to enable the physician to act in a professional capacity and consequently are not protected by the statute. Yet practically it is very unjust to a patient if his conversations with the physician can be sifted out by the law into two classes of utterances of which only one class is kept secret. What sort of confidence is secured by the statute if a sick and perhaps hysterical patient must be constantly on the alert, every time a question is asked him, to determine at his peril whether it is necessary for treatment, and, even if it is, must be watchful lest he add something to his answer which is not necessary? If the privilege is to exist at all, the law might well take the position that all the communications of the patient which are actuated by his feeling of confidence in his medical adviser and which he would naturally make in furnishing the doctor with information as a basis of treatment are entitled to secrecy, even though some of these facts if wrenched from the conversation and taken singly have no medical value. A patient should not be forced to tell his story to the doctor with the circumspection of a lawyer drawing pleadings.

The privilege belongs to the patient and not to the physician. Hence the patient cannot be forced to testify about the consultation any more than can the doctor. Conversely, if the patient consents to the disclosure, the doctor can no longer insist on remaining silent. The effectiveness of anything less than express consent, however, raises a perplexing issue. ${ }^{32}$ Suppose, for example, the plaintiff in a personal injury case, who has been to several doctors, calls only one physician who is favorable to his own claim. There is great confusion as to whether the plaintiff can still insist that it might cause him "embarrassment and disgrace" if the defense were allowed to put on his other doctors who are ready to tell a very different story about the plaintiff's bodily condition..$^{33}$

If the patient is dead and can no longer waive his privilege, must the doctor's lips then be sealed forever? Some statutes have neglected to provide for this emergency, while others expressly permit the executor or administrator of the patient to authorize the doctor to speak. ${ }^{34}$ Yet no

31. If the doctor were a psychiatrist, who was curing her of melancholia or some other mental or nervous disorder, questions on such a fact would be highly important.

32. The effect of the patient's testifying about his own health has already been discussed. See p. 610 supra.

33. See Comment (1922) 31 Yale L. J. 529 ; Notes (1929) 62 A. L. R. 680, (1934) 90 A. L. R. 646; (1938) 51 HARv. L. REv. 931.

34. The cases are collected in Notes (1924) 31 A. L. R. 167, (1940) 126 A. L. R. $380 ; 8$ WigMCRE, EVIDENCE, §2391. 
matter how carefully the statute is drawn, it may fáil to specify some person connected with the decedent who has an excellent reason for desiring the doctor's testimony. For example, in a IVisconsin case a widow: suing as a beneficiary under an accident insurance policy was unable to prove that her husband's death was accidental except by the testimony of the physician who attended him. The IVisconsin statute did not say that a beneficiary could waive the privilege; the court forced the doctor to keep silent, and the widow recovered nothing on the policy. ${ }^{35}$ Here the privilege, which is supposed to exist for the patient's henefit, operated to defeat one of his dearest desires. Wigmore's riew that nobody except the patient may take advantage of the privilege would have accomplished a just result in this case. Certainly a person directly antagonistic to the patient should not profit from the privilege. ${ }^{30}$

The possibility that the patient's death silences the doctor is particularly objectionable when the patient was murdered. It may be very important to have a physician disclose the physical condition of the victim during the interval between the crime and the death. Sometimes a man kills a woman to get her out of the way because she is expecting a child, and medical testimony is necessary to establish his motive. Judges usually obviate this difficulty by saying that criminal cases are not within the spirit of the statute, although some courts refuse to carve out such an exception. $^{37}$ Usually the desired testimony relates to the bodily condition of the victim, but it may conceivably concern that of the accused and here the bars have been higher. ${ }^{38}$ Suppose a murder on a dark street. A policeman testifies that he could not recognize the killer, but that he shot at him as he was running away and hit him in the left arm. The prosecution calls a physician for the purpose of having him testify that one hour after the murder the accused called at his office and was treated for a bullet-wound in his left arm. The accused objects on the ground that he does not want to disclose his ailments to the public. It is by no means certain on the authorities that the doctor would be allowed to testify, and so the prisoner might be acquitted for inability to identify him as the murderer. ${ }^{50}$

35. Maine v. Maryland Casualty Co., 172 Wis. 350, 178 N. WV. 749 (1920) (two judges dissenting) ; Note (1921) 15 A. L. R. 1544.

36. Many insurance policies endeavor to avoid such difficulties by a clause in which the insured waives the privilege in advance. Such a clause is usually held valid, but it has no effect in New York. The cases are collected in Note (1928) 54 A. L. R. 412; 1 WigMrore, EVIDENCE, § 7a.

37. The cases are collected in Note (1926) 45 A. L. R. 1357; \& Wrg:sore, Emierice, $\S 2385$.

38. See People v. Murphy, 101 N. Y. 126, 4 N. E. 326 (18s5).

39. A similar but much more perplexing conflict of loyalties was presented to Dr. C. E. May of Minnesota. While Dillinger, the former Public Enemy No. 1, was fleeing from prison, he went to Dr. May to be treated for gunshot wounds incurred during his escape. Was Dr. May ethically bound as a physician to preserve secrecy or was he under a duty as a citizen to notify the police? In fact he neglected to inform the police of his ministrations and was consequently imprisoned two years for harboring a fugitive wantcd 
The Code of Evidence recently published by the American Law Institute ${ }^{40}$ was originally drawn without any privilege for medical secrets in court. ${ }^{41}$ At the last minute lawyers from states which have the privilege in their statutes forced the draftsmen of the Code to insert three new sections ( $\S \S 221-223$ ) establishing the physician-patient privilege. Fortunately, numerous limitations are specified which will prevent a repetition of many of the miscarriages of justice already described above. It may be argued in defense of the Code that these limitations greatly improve the law in states where the privilege now exists. Nevertheless, the American Law Institute might better have adopted a complete reform. In the first place, no matter how numerous and careful the limitations, some new situation is bound to arise where secrecy ought not to be maintained; yet the Code will prevent disclosure because the draftsmen in 1942 could not foresee this situation and so failed to insert any limitation to take care of it. Secondly, although the Code will help make the law better in states which now have the privilege, it will help make the law worse in states which have hitherto let in the truth. The powerful influence of the American Law Institute is likely ultimately to cause the general adoption of the Code in all the states, including those which now reject the doctor-patient privilege. Thus truth will be curtailed in regions where it is now available without any apparent corresponding gain of medical care. In Massachusetts, for instance, the doctor is now protected by the trial judge against needless disclosures, but told to speak out when truth is important. If Massachusetts should enact the Code of Evidence, many hours and many dollars would be spent on the intricacies of this new privilege ${ }^{42}$ and sooner or later some badly needed testimony would be lost. But what would health gain? Does anybody seriously believe that the Massachusetts General Hospital or the Boston Lying-In Hospital would suddenly rise to new heights of excellence because patients could throng to them assured that if they should ever get into litigation a few of their medical secrets would occasionally be hidden from the prying curiosity of judges and jurors?

While the law has been so solicitous about the doctor's duty to keep silent on the witness-stand, it has done little to protect the patient's medical secrets from disclosure to the world in general. No statute requires

under a federal warrant. The Lancet commented that "colleagues in every country will applaud his action in not betraying a professional trust." (1934) 226 LANCET 1183. Not many laymen are likely to join in the applause.

40. See Morgan, loc. cit. supra note 9.

41. See Restatement, Evidevce (Proposed Final Draft, March 16, 1942, submitted to the Annual Meeting, May, 1942).

42. The New York doctor-patient statute (Civit. Practice ACr $\$ 352$ ) is twelve lines long, and it takes eight pages of small type just to summarize briefly the judicial decisions interpreting these lines. See 3B Gilbert-Bliss, Civid Practice of NEw York ANN. (1942) $180-87$. 
the doctor to pay damages to his patient. At common law, untruthful statements by the doctor may constitute actionable defamation, ${ }^{43}$ but if he tells the truth in breach of confidence it is very doubtful whether he incurs any contractual liability. Recovery was denied the patient in the only case in point, Simonsen a. Süchsen. ${ }^{\text {it }}$ A guest of a small hotel in a Nebraska town consulted a doctor who diagnosed his ailment as syphilis. He told the patient of the danger of communication and got his promise to leave the hotel the next day. On that day the doctor made a professional call on the owner of the hotel, and on finding that the patient had not moved out he warned the owner that the man had "a cuntagious disease." The patient was forced to leave the hotel, and sued the doctor for disclosing medical secrets. The Nebraska court thought that a ductur ought to pay damages for telling the truth in breach of the confidential relation to his patient, but that he should have the same right as a man who is sued for slander to insist that he acted under a duty to make the disclosure, which was more important than the duty to keep silent. Clearly his statutory obligation to make health reports would justify breaches of confidence therein. Here, however, he was under no legal obligation to divulge his patient's disease; but the court decided that in view of the great danger to life resulting from silence he had a moral obligation to speak which overrode his duty of secrecy. Consequently, the patient lost his case.

Much can be said for and against this result. One commentator says that the Nebraska case "stands for the triumph of medical altruism over legal duty." "45 Certainly, disclosure of risks of infection is very desirable; but it would be wiser to require all contagious diseases to be reported to a public official, who should have power to take all steps necessary to protect people from the patient, whether this required publicity or his removal to a hospital. There are obvious dangers in leaving it to every physician to determine whether circumstances justify him in betraying intimate confidences to the lay public.

Legislatures and courts have been occupied for over a century in closing the physician's mouth in the very place where the truth is badly needed. And yet the much more important obligation of his silence in private life has hardly been considered. In the few instances where honest patients do dread disclosure of their physical condition by a doctor, their fear is not that the truth may some day be forced from him in court, but that he may voluntarily spread the facts among his friends and theirs in conversation. Yet against this really dangerous possibility the statutes and courts give almost no protection.

43. See Smith v. Driscoll, 94 Wash. 441, 162 Pac. 572 (1917).

44. 104 Neb. 224, 177 N. W. $\$ 31$ (1920), 9 A. L. K. 1254, (1921) 30 Y.uLE L. J. 289, (1920) 20 Col L. REv. 890, (1921) 34 HARv. L. Kev. 312, (1920) 75 J. AM. MED. Ass'x 1207 .

45. (1921) 34 HARv. L. Kev. 312, 314. 